\title{
Association between Meteorological Parameters and SARS-CoV-2 Outbreak Trends in Major Divisions of Bangladesh
}

\author{
M. H. Masum*, S. K. Pal \\ Department of Civil Engineering, Chittagong University of Engineering \& Technology, \\ Chattogram-4349, Bangladesh
}

Received 10 January 2021, accepted in final revised form 26 May 2021

\begin{abstract}
Severe Acute Respiratory Syndrome Coronavirus-2 (SARS-CoV-2) has caused the current pandemic situation worldwide. Studies based on different factors affecting the pandemic are useful in order to find effective measures against COVID-19. Therefore, this study aims to explore the association between meteorological parameters and COVID-19 positive cases, along with a number of fatalities. In this study, the number of identified COVID-19 cases along with death figures, daily records of rainfall, temperature, relative humidity, and wind speed were collected from April and May 2020 for eight major divisions in Bangladesh. Significant positive association ( $r=0.24$ to 0.58 ) between relative humidity and COVID-19 cases across the cities was found in this study, while for temperature both positive and negative associations ( $r=-0.23$ to 0.72$)$ were observed. Similarly, a positive association is found between humidity $((r=-0.012$ to 0.384$))$ and numbers of COVID-19 death cases. Rainfall and wind speed exhibit positive correlations with COVID-19 positive cases and numbers of death cases. The findings of the study surely help the policymaker for further decision making, conducting new study and initiate the mitigation measures against COVID-19.
\end{abstract}

Keywords: COVID-19; SPSS; ArcGIS; Humidity; Temperature.

(c) 2021 JSR Publications. ISSN: 2070-0237 (Print); 2070-0245 (Online). All rights reserved. doi: http://dx.doi.org/10.3329/jsr.v13i3.51297 J. Sci. Res. 13 (3), 763-777 (2021)

\section{Introduction}

COVID-19 has caused a sizeable global outbreak situation and has caused a pandemic worldwide since then. The devastating attack is evident in most countries, including China, India, the United States of America, Italy, France, Spain, the United Kingdom, Brazil, and many other countries. COVID-19 virus is seen to be highly transmissible by contact or staying closer than 3 to $6 \mathrm{~m}$ of affected people or from anything in human body contact and the human body to human body. Therefore, maintaining social distance, wearing masks, washing hands, and clothes are advised by WHO and respective health organizations. COVID-19 situation causes worldwide distress in the social and economic sector also with demographic changes and unemployment. Transportation, travel and

\footnotetext{
*Corresponding author: mehedi.ce.cuet@gmail.com
} 
tourism industries are facing tremendous financial crises, despite a cleaner environment being found worldwide [1]. COVID-19 pandemic situation shows that science has a longterm future perspective. It is time to implement different methods i.e., deep neural network (DNN), convolutional neural network (CNN), Artificial neural network ANN, RT-PCR, CT scan etc., in the clinical sector to help frontline doctors and staffs in order to diagnosis possible fast and better ways [2]. Different countries initiated lockdown thereafter to reduce the spreading of COVID-19 virus and imposed health regulations. In relation to this, the first three cases of COVID-19 were registered on March 8, 2020 in Bangladesh [3]. Therefore, the Government of Bangladesh (GoB) declared 10 days lockdown on 16 March, 2020 to be executed from 26 March, 2020 to 4 April, 2020 at first instance then it continued till 30 May, 2020 following six more spells of lockdown [4]. However, decision to resume garment industries maintaining health regulations on 26 April, 2020 eventually put the lockdown measures in vain [5]. Starting a business as usual from 31 May, 2020, Bangladesh saw its worst scenarios of affected cases and death toll rates are still upward with an average of approximately $3 \%$ of total tests conducted and $1.8 \%$ of total affected, respectively [3]. The figures may not likely very hopeless compared with other countries to date. However, no hope of light may be seen even after 110 days since its journey in Bangladesh, while many other countries already saw the trend downward.

COVID-19 forecasting and association with environmental parameters are essential to evaluate an overview COVID-19 cases rate and therefore, these can be taken into consideration in taking the prevention measures in order to control the spreading of disease [6]. Forecasting the cases and death rate with environmental parameters association surely softens the anxiety of frontline medical doctors and staff by paying special attributes [7]. Considering the climatic variability that exists in different parts of the world addresses the question of whether climatic factors have influences in spreading SARS-Cov-2 or COVID-19 virus. Islam and Naqib found that temperature and relative humidity affect the suspension time of the exhaled aerosols/droplets at varying degrees, particularly for those with small radii [8]. A significant association was detected by Sharif and Dey [9] among the density of population and confirmed positive cases in Bangladesh and found that the mobility and crowd are responsible for increasing the COVID-19 cases and fatalities. Ahmadi et al. [10] have investigated the effects of climatology parameters on COVID-19 outbreak in Iran and found that temperature and rainfall have a positive relationship, and humidity, wind speed and solar radiation have negative effects on COVID-19 outbreak, especially on infected cases. Biktasheva [11] found that local air humidity has a negative correlation with COVID-19 mortality in German federal states. In this line, the positive correlation for diurnal temperature $(r=0.44)$ but negative for relative humidity ( $r=-0.32$ ) with COVID-19 daily mortality counts in Wuhan, China are reported by Ma et al. [12]. The same study also revealed that absolute humidity has a positive correlation with the death counts. Furthermore, Bilal et al. reported that environmental pollution parameters have significantly contributed in South America to the spreading of COVID-19 and the rising of death rates [13]. In contrast, Qi et al. [14] 
reported that both average temperature and average humidity negatively correlate with COVID-19 transmission in Mainland China. A similar result has been reported by Sahin [15] using 9 major cities in Turkey with spatial variabilities. Furthermore, Menebo [16] noted the maximum temperature, minimum temperature, normal temperature, average temperature, wind speed have positively associated with daily new cases, while the precipitation exhibit a negative association in Oslo, Norway. Another study by Tosepu et al. [17] reported that the temperature, humidity and rainfall on COVID-19 cases have a positive association with the COVID-19 cases in Jakarta, Indonesia. All these studies claimed the association of climatic factors on COVID-19 cases and death tolls. It is clear from the outcomes of these studies that the climatic parameters might have associations with COVID-19 cases and death tolls that are different in different regions; hence, a few more local/regional studies may further deepen the claims in contexts of variation in climatic pattern. If the claims are true, then it can worth investigating its effect on affected cases and death tolls influenced by changing weather ahead to portray the probable scenarios to be seen. Identification of weather parameters (i.e., rainfall, temperature, humidity, wind speed etc.) and COVID-19 outbreak indicators (confirmed positive cases and fatalities) that may have an influence on SARS-Cov-2 coronavirus disease spreading and mortality rate in different countries is essential for better management and policymaking of this tremendous infectious disease. Therefore, the main objective of the study is to establish the association between weather parameters with COVID-19 confirmed positive cases and numbers of death cases during the lockdown period in eight administrative divisions of Bangladesh. Spatial variation of weather parameters, COVID19 positive cases and COVID-19 death cases are also evaluated.

\section{Methodology}

\subsection{Study area}

Bangladesh (as seen in Fig. 1) is situated in $20^{\circ} 34^{\prime} \mathrm{N}$ to $26^{\circ} 38^{\prime} \mathrm{N}$ latitude and $88^{\circ} 01^{\prime} \mathrm{E}$ to $92^{\circ} 41^{\prime} \mathrm{E}$ longitude. Bangladesh is the eighth-most populous country in the world, having more than 166 million people in an area of $148,460 \mathrm{~km}^{2}$. The country shares its land borders with India to the west, north, and east, Myanmar to the southeast, the Bay of Bangle in the south, the Assam Hills in the east, and the lofty Himalayas to the north. Bangladesh is in the tropical monsoon region with the warm temperature and high humidity. Major four seasons are found in Bangladesh, namely, Pre-monsoon (MarchMay), Monsoon (June-September), Post- Monsoon (October-November) and Winter (December- February). The annual maximum temperature of the country ranges between $30{ }^{\circ} \mathrm{C}$ to $40{ }^{\circ} \mathrm{C}$ during the warm period, whereas the average temperature becomes $10{ }^{\circ} \mathrm{C}$ during the winter season. The average annual rainfall of the country is about $1600 \mathrm{~mm}$, but most of the areas receive more than $2000 \mathrm{~mm}$ rainfall per year. Bangladesh has eight divisions, namely Barishal (BAR), Chittagong (CTG), Dhaka (DHK), Khulna (KHU), Mymensingh (MYM), Rajshahi (RAJ), Rangpur (RAN) and Sylhet (SYL). The density of eight divisions varies from 691 to 1951 people per square kilometer [18]. 


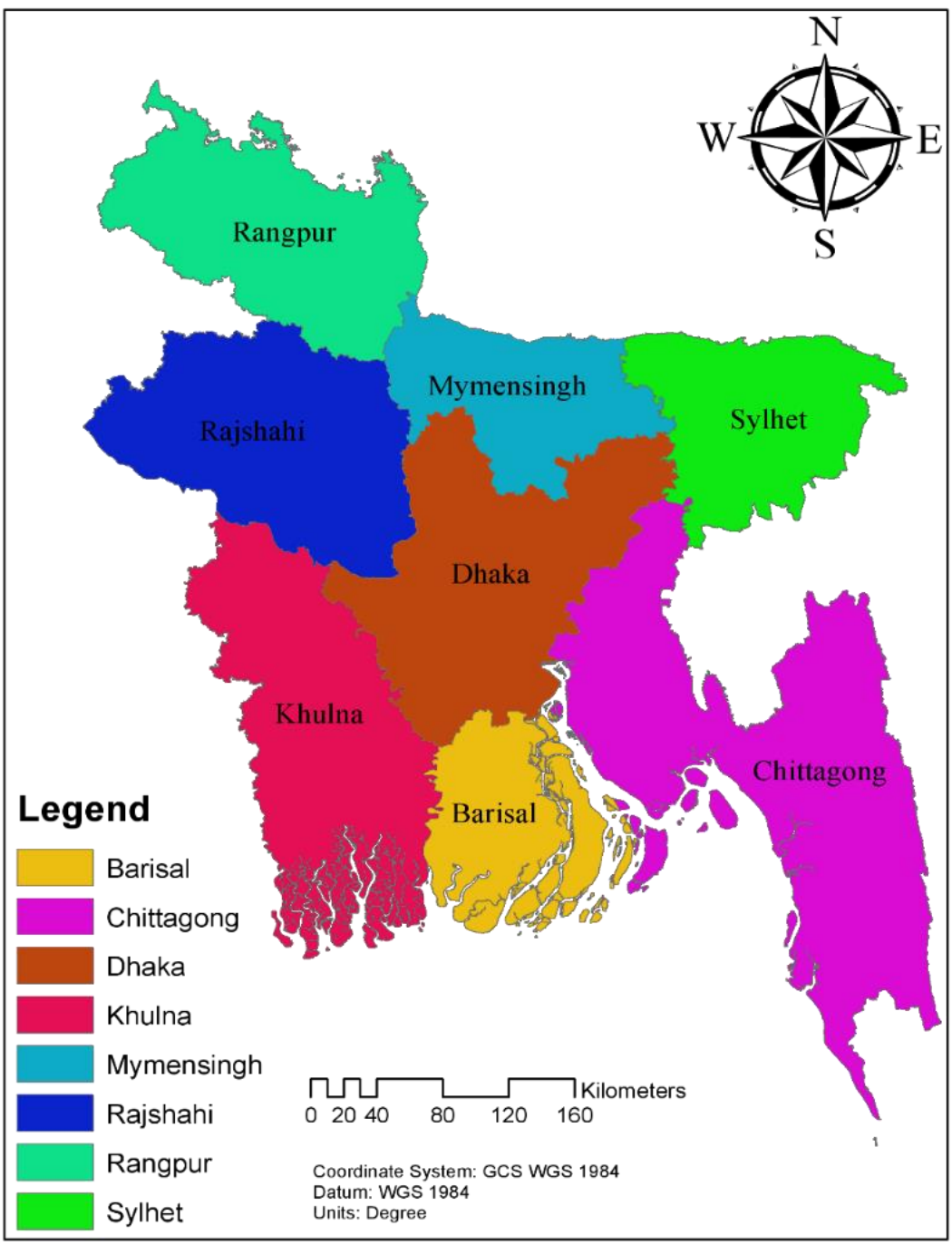

Fig. 1. The map showing the eight divisions in Bangladesh.

\subsection{Data collection}

Daily data of weather parameters (rainfall, temperature, relative humidity and wind speed) has been collected from the Bangladesh Meteorological Department (BMD) for April and May 2020 for eight divisions of Bangladesh [19]. The number of COVID-19 infected cases and death cases have been collected from the Institute of Epidemiology, Disease Control and Research (IEDCR) and Directorate General of Health Services (DGHS) for the same period $[3,20]$. 


\subsection{Statistical analyses}

Descriptive statistics, trend analyses, data homogeneity, data standardized were performed using SPSS ver. 23. Due to the variable nature of different climatic parameters and as suggested by others for alike studies elsewhere in Norway [16], Turkey [15], Indonesia [17], Singapore [21], USA [22], the Spearman's rank correlation analysis was performed to evaluate the relationship between the different climatic parameters (i.e., rainfall, temperature, humidity, wind speed, etc.) and COVID-19 variables (i.e., cases, deaths etc.). The Spearman's rank correlation analysis demonstrates the relationship between climatic variables and the number of COVID-19 positive cases. During correlation analysis, the climatic parameters lag by 3-, 7-, and 14-days earlier date were also considered along with the current date COVID-19 cases with same day climatic variables based on the assumption that the people got affected may not necessarily expose to the same day climatic parameters as symptom initiation takes a couple of days to two weeks in many cases. Regarding Spearman's rank correlation [23] as shown in Eq. (1), it is a useful technique for determining correlation coefficients between variables not normally distributed using a monotonic function. The following equation is used to compute the correlation coefficients.

$$
r_{s}=1-6 \frac{\sum d_{i}^{2}}{n\left(n^{2}-1\right)}
$$

where $n$ indicates the number of alternatives, and $d_{i}$ represents the difference between the ranks of two parameters. In this study, confidence intervals of $95 \%$ and $99 \%(p<0.05, p$ $<0.01)$ are considered for the acceptable level of association between any two variables.

\section{Results and Discussion}

\subsection{Descriptive statistics of climatic parameters}

Table 1 presents the descriptive statistics of temperature $(T)$, relative humidity $(R h)$, precipitation $(R)$ and wind speed $(u)$ as obtained from the daily records for the studied duration of eight divisions in Bangladesh. Along with these, a total number of COVID-19 positive cases for March to May 2020 are also reported in Table 1. As seen in Table 1, the weather is in general warm with relatively high humidity with a few occasional precipitations across the sites. The variation of the mean temperature, relative humidity, precipitation and wind speed across the sites are in the range of 28 to $32{ }^{\circ} \mathrm{C}, 49$ to $67 \%$, 0.3 to $2.1 \mathrm{~mm}$ and 6.9 to $15.8 \mathrm{~km} / \mathrm{h}$, respectively, portraying somewhat variability across the sites. Based on the total registered COVID-19 positive cases during the studied duration (April to May 2020), it has been seen that the cases are significantly higher in Dhaka and Chittagong than in other major cities (see Table 1) attributes to population density, very typical unplanned urban settings and commercial activities in the two largest cities in Bangladesh. 
Table 1. Descriptive statistics of the climatic variables along with COVID-19 registered cases in Bangladesh in April - May 2020.

\begin{tabular}{|c|c|c|c|c|c|c|c|c|c|}
\hline \multicolumn{2}{|c|}{ Parameters } & DHK & CTG & RAJ & SYL & MYM & RAN & BAR & KHU \\
\hline \multirow{3}{*}{$\begin{array}{l}\text { Rainfall } \\
(\mathrm{mm})\end{array}$} & Min-Max & $0-5.1$ & $0-3.3$ & $0-29.8$ & $0-16.7$ & $0-9.8$ & $0-18.1$ & $0-3.7$ & $0-7.0$ \\
\hline & Mean \pm SD & $9 \pm 1.4$ & $.5 \pm 0.8$ & $1.1 \pm 3.9$ & $2.1 \pm 3.5$ & $1.0 \pm 1.7$ & $1.4 \pm 3.2$ & $0.3 \pm 0.6$ & $0.7 \pm 1.3$ \\
\hline & $\mathrm{CV}(\%)$ & 1.7 & 1.8 & 3.5 & 1.6 & 1.8 & 2.2 & 2.3 & 2.0 \\
\hline elative & Min-Max & $28-76$ & $60-86$ & $12-90$ & $24-89$ & $22-87$ & 14-94 & $40-75$ & $14-76$ \\
\hline & Mean & $57 \pm 9$ & $76 \pm 5$ & $49 \pm 17$ & $66 \pm 15$ & $58 \pm 15$ & $53 \pm 20$ & $67 \pm 7$ & $65 \pm 9$ \\
\hline 6 & CV $(\%)$ & 0.2 & 0.1 & 0.3 & 0.2 & 0.3 & 0.4 & 0.1 & 0.1 \\
\hline \multirow{3}{*}{ Temp. } & Min- & 7-34 & $27-31$ & $25-36$ & $25-32$ & $26-34$ & $23-33$ & $26-34$ & $27-34$ \\
\hline & Mea & $32 \pm 2$ & $28 \pm 1$ & $32 \pm 3$ & $29 \pm 2$ & $30 \pm 2$ & $29 \pm 2$ & $30 \pm 2$ & $31 \pm 2$ \\
\hline & $\mathrm{CV}($ & 0.1 & 0.0 & 0.1 & 0.1 & 0.1 & 0.1 & 0.1 & 0.1 \\
\hline Find & Min & $8-37.4$ & $.5-37.3$ & $6.5-37.2$ & $3.3-15.0$ & $5.3-29.5$ & $5.0-47$ & $6.0-30$ & $6.0-32$ \\
\hline & Mec & $14 \pm 6$ & $16 \pm 5$ & $13 \pm 6$ & $7 \pm 3$ & 11 & $13 \pm 6$ & $14 \pm 6$ & $14 \pm 6$ \\
\hline$(\mathrm{Km} / \mathrm{hr})$ & CV $(\%)$ & 0.5 & 0.3 & 0.4 & 0.4 & 0.4 & 0.5 & 0.4 & 0.4 \\
\hline OVID-19 & Min-1 & $0-4690$ & & $0-2$ & $0-307$ & & $0-239$ & $0-66$ & $0-94$ \\
\hline sitive & Mean & $461 \pm 690$ & $108 \pm 247$ & $16 \pm 45$ & $15 \pm 45$ & $20 \pm 33$ & $19 \pm 36$ & $7 \pm 12$ & $12 \pm 18$ \\
\hline cases & CV (\%) & 1.5 & 2.3 & 2.8 & 3.0 & 1.7 & 2.0 & 1.8 & 1.5 \\
\hline Nos. death & Min-Max & $0-28.0$ & $0-10.0$ & $0-2.0$ & $0-3.0$ & $0-2.0$ & $0-3.0$ & $0-2.0$ & $0-2.0$ \\
\hline to & & $7.0 \pm 5.2$ & $2.4 \pm 3.1$ & $0.2 \pm 0.4$ & $0.3 \pm 0.6$ & $0.2 \pm 0.5$ & $0.3 \pm 0.7$ & $0.1 \pm 0.4$ & $0.1 \pm 0.4$ \\
\hline OVID-19 & $\mathrm{CV}(\%)$ & 0.7 & 1.3 & 2.2 & 2.0 & 2.6 & 2.4 & 3.2 & 3.2 \\
\hline
\end{tabular}

Note: Min: Minimum; Max: Maximum; SD: Standard Deviation; CV: Coefficient of Variation

The trend analysis of daily data for the aforesaid climatic parameters illustrates that notable precipitation was observed on 19 April, 19 and 29 May during March to May 2020 and that dropped down the values of temperature and relative humidity for a subsequent couple of days. Although the number of positive cases is different in different places, in general, it follows temperature and relative humidity trends (Figs. 2(b,c)). Furthermore, from these Figs. 3 and 4, it has been seen that the COVID-19 cases were substantially low until 18 April 2020 since the first three positive cases registered on 8 March in Dhaka, while in contrast, the dramatically increased rate of both was found thereafter to date of writing following the pattern of increased temperature and relative humidity across the cities in Bangladesh. Among the cities, Dhaka and Chittagong accounted the greater numbers than others (Fig. 4). It is noted that in March, the inception of COVID-19 case in Dhaka, the typical weather pattern was seen just like post-winter comfortable with temperature around $25{ }^{\circ} \mathrm{C}$ with relatively low humidity, wind speed and no precipitation. The complete shutdown declared to avoid the spreading of COVID-19 transmission from 16 March to 16 April 2020 further controlled the COVID-19 cases. However, resuming business, offices and other activities since 16 April 2020, the increased growth of both positive cases and widespread transmission from Dhaka and Chittagong to other cities were found.

Variations of climatic parameters are shown in Figs. 2(a-d) and cumulative numbers of total COVID-19 affected patients and numbers of deaths due to COVID-19 are shown in Figs. 3 and 4. As seen in Fig. 2(a), there are no significant rainfall occurrences during the COVID-19 lockdown periods. Very little rainfall occurs from 18 April, 2020 and continues for few days. Temperature variation has been illustrated in Fig. 2(b). The 
temperature was almost steady up to 18 April, 2020. After that, the temperature starts to drop as rainfall happens. Later the temperature raised and became steady again. Relative Humidity shows an inverse relationship (Fig. 2(c)) with temperature. As the temperature decreases, the relative humidity increases. Wind speed during COVID-19 lockdown periods was almost steady (Fig. 2(d)) except last few days of an increasing trend. The variations of COVID-19 affected people have been illustrated in Fig. 3. The rate was almost low up to 18 April, 2020. After that, the rate of affected people increased sharply and continued. A similar trend is found in the case of a number of deaths, as shown in Fig. 4.
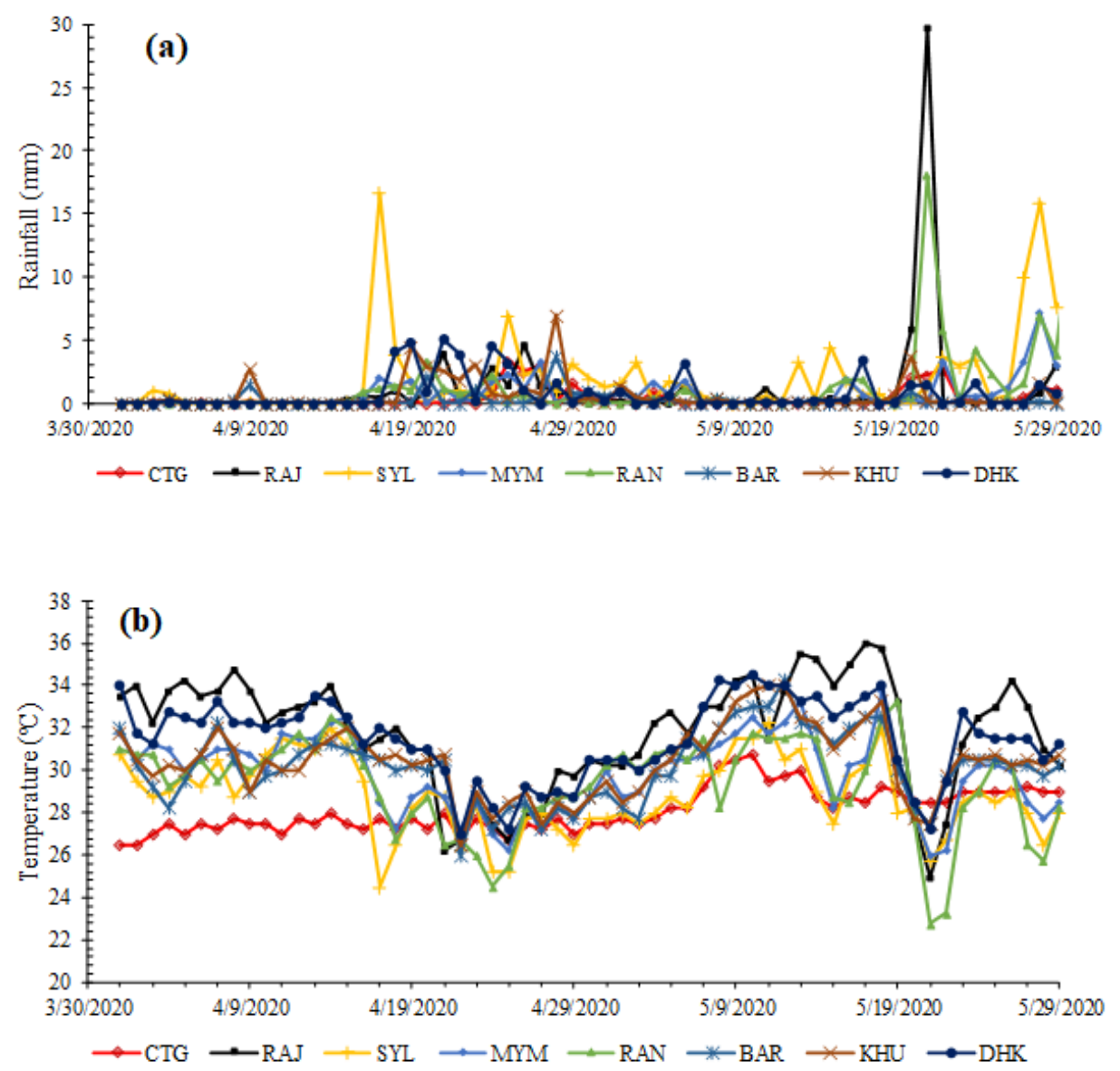

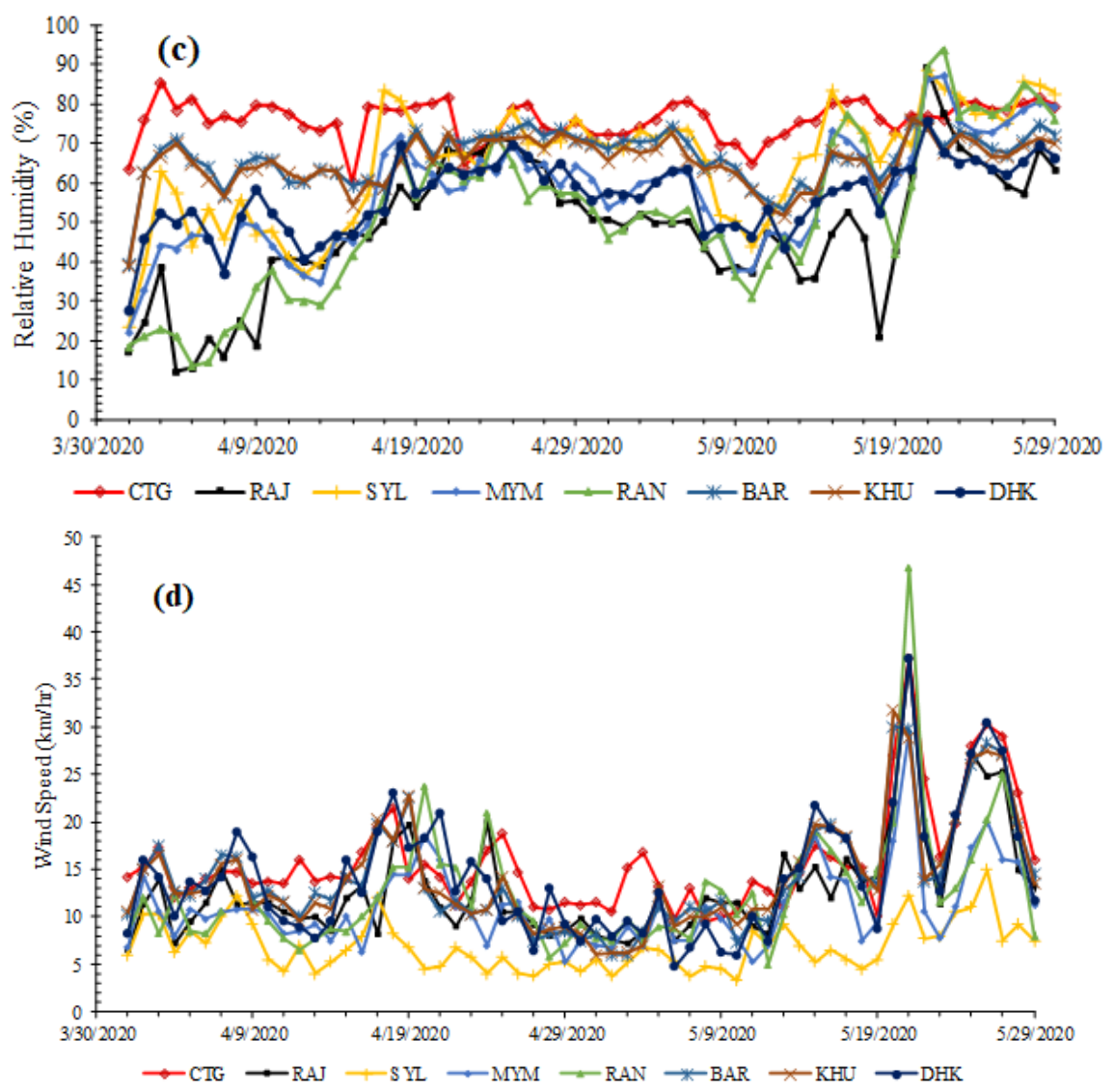

Fig. 2. Daily Variation of weather parameters, (a) rainfall, (b) temperature, (c) Humidity and (d) wind speed during COVID-19 lockdown.

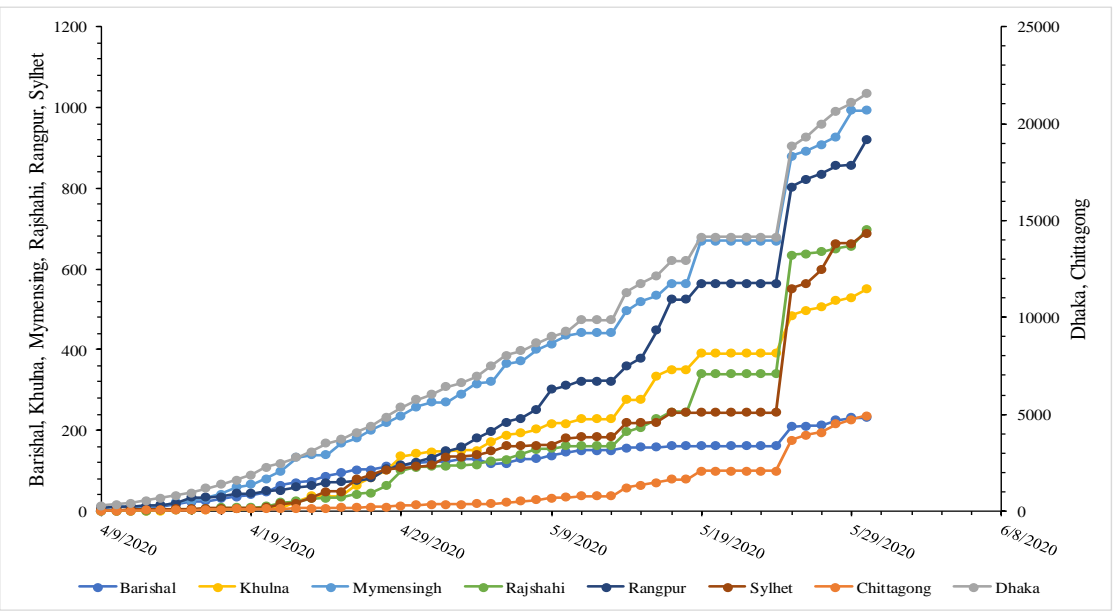

Fig. 3. Cumulative daily confirmed COVID-19 positive cases during lockdown. 


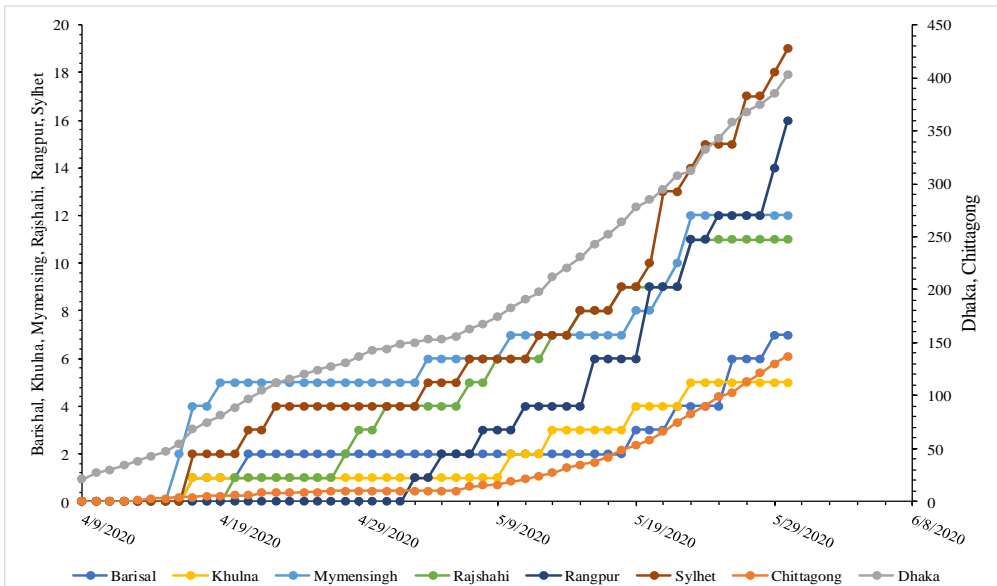

Fig. 4. Cumulative numbers of death due to COVID-19 pandemic during lockdown.

\subsection{Spatial Distribution of COVID-19 cases and numbers of deaths}

The result of spatial variation of confirmed COVID-19 positive cases (left) and a number of deaths is shown in Fig. 5. It clearly illustrates that the rate is high in the two megacities Dhaka and Chittagong division as the human activities is relatively high in these two divisions. In comparison, the number is fewer Barisal and Khulna divisions. The other divisions show an almost similar trend of COVID-19 cases and corresponding death rate during the lockdown.
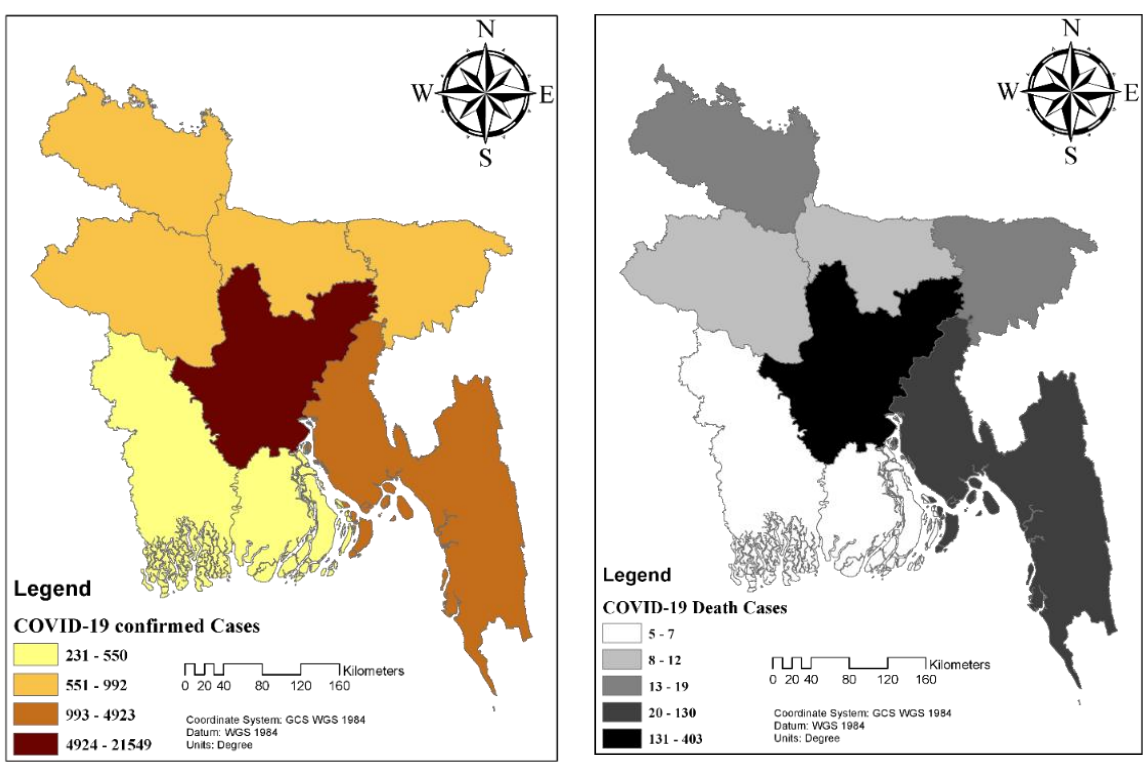

Fig. 5. Spatial distribution of confirmed COVID-19 positive cases (left) and numbers of death till to 30 May, 2020. 


\subsection{Association between weather parameters with COVID-19 cases}

The result of Spearman's rank correlation analysis between climatic parameters and the COVID-19 positive cases and a number of death cases have been represented in Tables 2 and Table 3. As mentioned earlier, four major climatic parameters, rainfall, temperature, relative humidity, wind speed are considered in the study. A few considerations have been taken before correlating the climatic parameters with COVID-19 pandemic. Firstly, the tests were conducted instantly without the requirement of any symptoms of COVID-19 or a public mass testing campaign, and for which the results were given instantly; hence, affected date and climatic information on the day are valid. Secondly, the tests were done based on symptoms followed by incubation periods as suggested by IEDCR. Testing has been conducted for people having COVID-19 symptoms (e.g., coughing, fever or respiratory difficulties). For this reason, the climatic parameters are evaluated for three timeframes, namely, 3 days, 7 days, 14 days before reporting the test result, as the patients having symptoms of COVID-19 were tested and due to limited kits and testing laboratories in Bangladesh, the test results were delayed in some cases even couple of weeks or so. In this alignment, it is well understood that the patients got affected earlier than the reported date. Therefore, climatic information of 3 days, 7 days or 14 days before the declared positive report was considered for the correlation analysis.

Table 2. The correlation coefficients between weather parameters and COVID-19 positive cases.

\begin{tabular}{|c|c|c|c|c|c|c|c|c|}
\hline Variables & DHK & CTG & RAJ & SYL & MYM & RAN & BAR & KHU \\
\hline $\mathrm{R}$ (Rain on day) & $0.406 * *$ & $0.360 * *$ & $0.252 *$ & $0.283 *$ & $0.271 *$ & $0.279 *$ & -0.107 & 0.121 \\
\hline R3 (Rain 3 days lag) & $0.279 *$ & $0.431 * *$ & $0.386 * *$ & $0.497 * *$ & $0.316^{*}$ & $0.321 * *$ & 0.028 & $0.283 *$ \\
\hline R7 (Rain 7 days lag) & $0.241 *$ & $0.364 * *$ & 0.050 & $0.341 * *$ & $0.299 *$ & 0.145 & -0.094 & 0.131 \\
\hline R14 (14 days lag) & 0.214 & $0.338 * *$ & 0.128 & 0.131 & 0.123 & $0.245 *$ & -0.167 & 0.117 \\
\hline RH (Humidity on day) & $0.581 * *$ & 0.145 & $0.400 * *$ & $0.311 *$ & $0.390 * *$ & $0.411 * *$ & $0.265 *$ & $0.295 *$ \\
\hline H3 (Humidity 3 days lag) & $0.525 * *$ & 0.056 & $0.568 * *$ & $0.492 * *$ & $0.303 *$ & $0.443 * *$ & 0.176 & $0.357 * *$ \\
\hline H7 (Humidity 7 days lag) & $0.404 * *$ & 0.015 & $0.402 * *$ & $0.502 * *$ & $0.275^{*}$ & $0.390 * *$ & $0.231 *$ & 0.209 \\
\hline H14 (Humidity 14 days lag) & $0.432 * *$ & -0.01 & $0.241 *$ & $0.242 *$ & $0.337 * *$ & $0.422 * *$ & 0.078 & $0.248 *$ \\
\hline $\mathrm{T}$ (Temperature on day) & -0.187 & $0.609 * *$ & -0.087 & -0.214 & $-0.272 *$ & 0.067 & -0.045 & -0.063 \\
\hline T3 (Temperature 3 days lag) & -0.124 & $0.721 * *$ & $-0.233^{*}$ & $-0.357 * *$ & -0.086 & -0.058 & -0.058 & -0.018 \\
\hline T7 (Temperature 3 days lag) & -0.13 & $0.676 * *$ & -0.051 & $-0.229 *$ & -0.137 & -0.032 & 0.024 & 0.153 \\
\hline $\begin{array}{l}\text { T14(Temperature } 14 \text { days } \\
\text { lag) }\end{array}$ & -0.119 & $0.674 * *$ & -0.068 & 0.031 & -0.193 & -0.089 & 0.161 & 0.034 \\
\hline W (Wind speed on day) & 0.082 & 0.081 & 0.067 & -0.048 & $0.279 *$ & 0.234 & -0.076 & 0.027 \\
\hline W3 (Wind speed 3 days lag) & 0.065 & 0.191 & 0.132 & -0.049 & -0.082 & 0.033 & -0.099 & 0.098 \\
\hline W7 (Wind speed 7 days lag) & 0.090 & 0.141 & $0.246 *$ & 0.140 & 0.017 & 0.076 & $0.317 * *$ & $0.241 *$ \\
\hline $\begin{array}{l}\text { W14 (wind speed } 14 \text { days } \\
\text { lag) }\end{array}$ & 0.156 & 0.117 & $0.293 *$ & 0.132 & 0.151 & $0.253 *$ & $0.369 * *$ & $0.255^{*}$ \\
\hline
\end{tabular}

As seen in Table 2, the correlation coefficients are found to be varied among the cities in Bangladesh. The association of climatic parameters with COVID-19 cases exhibits positive and negative relationships, with their magnitudes varying between poor and strong. In general, temperature except in Chittagong city showed a negative association with positive cases, although the number of statistically significant 
correlations are in few cases. In contrast, the strong positive and greater number of strong associations with all four times frame in Chittagong city put the opposite impression from other cities. Considering relative humidity, a greater number of significant positive correlations were seen across the cities (except Chittagong) with a magnitude range 0.231 to 0.581 . In general, 3 and 7 days earlier relative humidity data has shown a greater number of relatively strong correlations with positive cases than on date and 14 days earlier data. The result indicates that higher humidity favors the transmission of COVID19. Similar findings (Table 3) are also reported by Pani and Lin [21] in their study in Singapore. The temperature and humidity both are well documented in similar studies, with both positive and negative associations portraying different forms of thoughts and influences on transmission of COVID-19 cases. Tosepu et al. [17] and, Pani et al. [21] reported (Table 3) positive linear relationship between temperature and the number of positive cases from Indonesia and Singapore. On the contrary, Yao et al. [24] reported no such significant correlation between temperature and COVID-19 transmission. This study revealed that both high temperature and humidity could explain a better positive association in the case of COVID-19 transmission in a warmer region. Unlike other studies, this study also investigates the influence of precipitation on COVID-19 transmission, as in Bangladesh, June, July and August months belong to the monsoon period receiving a significant amount of precipitation causing flooding. As seen in Table 2 , precipitation, in general, showed positive yet poor to fair associations ( $r=0.241$ to 0.341) with COVID-19 cases for 3 and 7 days before reported cases, which also illustrates that precipitation may further increase the transmission if social distancing and health regulations are not maintained in extreme flood events, in particular in flood shelter, although the precipitation events may have dropped temperature and humidity by few points.

Table 3. Association of climatic parameters with COVID-19 confirmed Cases reported in different studies.

\begin{tabular}{|c|c|c|c|c|c|c|}
\hline Study Area & $\begin{array}{l}\text { Rainfall } \\
\text { in mm (coef.) }\end{array}$ & $\begin{array}{l}\text { Temp in }{ }^{\circ} \mathrm{C} \\
\text { (Coef.) }\end{array}$ & $\begin{array}{l}\text { Relative humidity } \\
\% \text { (coef.) }\end{array}$ & $\begin{array}{l}\text { Wind speed } \\
\mathrm{kmh}^{-1} \text { (coef.) }\end{array}$ & Time period & Ref. \\
\hline $\begin{array}{l}\text { Cities in } \\
\text { Bangladesh }\end{array}$ & $\begin{array}{l}3.3-29.8 \\
(0.241-0.497)\end{array}$ & $\begin{array}{l}22.8-34.5 \\
(-0.229-0.721)\end{array}$ & $\begin{array}{l}12-94 \\
(0.241-0.581)\end{array}$ & $\begin{array}{l}3.3-46.8 \\
(0.241-0.369)\end{array}$ & $\begin{array}{l}8 \text { Mar }-31 \\
\text { May } 2020\end{array}$ & $\begin{array}{l}\text { This } \\
\text { Study }\end{array}$ \\
\hline $\begin{array}{l}\text { Jakarta, } \\
\text { Indonesia }\end{array}$ & $\begin{array}{l}1.1-88 \\
(0.139)\end{array}$ & $\begin{array}{l}26.1-28.6 \\
(0.392)\end{array}$ & $\begin{array}{l}75-93 \\
(0.002)\end{array}$ & $\mathrm{n} / \mathrm{a}$ & $\begin{array}{l}\text { 01 Jan - 29 } \\
\text { Mar 2020 }\end{array}$ & {$[17]$} \\
\hline $\begin{array}{l}\text { Wuhan, } \\
\text { China }\end{array}$ & $\mathrm{n} / \mathrm{a}$ & $\begin{array}{l}7.44 \pm 3.96 \\
(0.30)\end{array}$ & $\begin{array}{l}82.24 \pm 8.51 \\
(-0.32) \\
\end{array}$ & $\mathrm{n} / \mathrm{a}$ & $\begin{array}{l}20 \mathrm{Jan}-29 \mathrm{Feb} \\
2020\end{array}$ & [12] \\
\hline $\begin{array}{l}\text { Mainland } \\
\text { China }\end{array}$ & $\mathrm{n} / \mathrm{a}$ & $\begin{array}{l}-16.9-19.3 \\
(\mathrm{n} / \mathrm{a})\end{array}$ & $\begin{array}{l}17.93-86.20 \\
(\mathrm{n} / \mathrm{a})\end{array}$ & $\mathrm{n} / \mathrm{a}$ & $\begin{array}{l}20 \mathrm{Jan}-11 \mathrm{Feb} \\
2020\end{array}$ & [14] \\
\hline $\begin{array}{l}\text { Cities in } \\
\text { Pakistan }\end{array}$ & $\begin{array}{l}0.17-3.48 \\
(-0.26-0.081)\end{array}$ & $\begin{array}{l}1.87-33.99 \\
(0.66-0.84)\end{array}$ & $\begin{array}{l}32.16-61.47 \\
(-0.72-0.59)\end{array}$ & $\mathrm{n} / \mathrm{a}$ & $\begin{array}{l}16 \mathrm{Feb}-31 \mathrm{Jul} \\
2020\end{array}$ & [25] \\
\hline Cities in Iran & $\begin{array}{l}20.03 \pm 8.37 \\
(0.029)\end{array}$ & $\begin{array}{l}8.32 \pm 4.55 \\
(0.028)\end{array}$ & $\mathrm{n} / \mathrm{a}$ & $\begin{array}{l}12.73 \pm 2.30 \\
(-0.358)\end{array}$ & $\begin{array}{l}19 \text { Feb - } 22 \\
\text { Mar 2020 }\end{array}$ & [10] \\
\hline $\begin{array}{l}\text { Oslo, } \\
\text { Norway }\end{array}$ & $\begin{array}{l}1.19 \\
(-0.285) \\
\end{array}$ & $\begin{array}{l}4.76 \\
(0.224)\end{array}$ & $\mathrm{n} / \mathrm{a}$ & $\begin{array}{l}11.95 \\
(0.174)\end{array}$ & $\begin{array}{l}27 \mathrm{Feb}-02 \\
\text { May } 2020\end{array}$ & [16] \\
\hline $\begin{array}{l}\text { Cities in } \\
\text { Turkey }\end{array}$ & $\mathrm{n} / \mathrm{a}$ & $\begin{array}{l}11.8-17.7 \\
(-0.483)\end{array}$ & $\begin{array}{l}93.6(\max ) \\
(-0.317)\end{array}$ & $\begin{array}{l}49.41(\max ) \\
(-0.217)\end{array}$ & $\begin{array}{l}21 \text { Mar- } 03 \\
\text { Apr } 2020\end{array}$ & [15] \\
\hline
\end{tabular}




\begin{tabular}{lllllll}
\hline Study Area & $\begin{array}{l}\text { Rainfall } \\
\text { in mm (coef.) }\end{array}$ & $\begin{array}{l}\text { Temp in }{ }^{\circ} \mathrm{C} \\
\text { (Coef.) }\end{array}$ & $\begin{array}{l}\text { Relative humidity } \\
\% \text { (coef.) }\end{array}$ & $\begin{array}{l}\text { Wind speed } \\
\mathrm{kmh}^{-1} \text { (coef.) }\end{array}$ & Time period & Ref. \\
\hline Spain & $\mathrm{n} / \mathrm{a}$ & $\begin{array}{l}15.44 \pm 2.63 \\
(0.234)\end{array}$ & $\mathrm{n} / \mathrm{a}$ & $\mathrm{n} / \mathrm{a}$ & April 2020 & [26] \\
& & $\begin{array}{l}22.30 \pm 7.33 \\
\text { India }\end{array}$ & $\mathrm{n} / \mathrm{a}$ & $\begin{array}{l}5.97 \pm 1.764 \\
(0.178)\end{array}$ & April 2020 & [27] \\
& $(-0.285)$ & $(0.269)$ & & & & \\
\hline
\end{tabular}

Note: Correlation coefficients are kept within the bracket.

A similar positive correlation with precipitation was reported by Ahmadi et al. [10] from Iran. In the case of wind speed, a few significant positive correlations yet poor $(\mathrm{r}=$ 0.241 to 0.369 ) were found with the COVID-19 confirmed cases for 7 and 14 days before reporting. Similar to this study, Menebo [16] in Oslo, Norway, Bashir et al. [15] in New York, USA and Sahin [15] in Turkey reported a positive correlation with wind speed and COVID-19 cases. However, a negative correlation with wind speed 14 days before the cases was also noted by Menebo [16] and on day wind speed by Pani et al. [21].

\subsection{Correlation in-between climatic parameters with COVID-19 death cases}

As seen in Table 4, the correlation coefficients among climatic parameters and number of death cases are found significantly varying among the major cities of Bangladesh. Table 5 represents the international perspective of the association between climatic parameters and COVID-19 death cases in different regions of the world. The relationship between four climatic parameters with a number of COVID-19 death cases in major cities of Bangladesh shows both positive and negative relationships. Moreover, the magnitude of coefficients is also found to vary significantly between poor to strong. It is found that relative humidity showed a positive association with death cases in most of the major cities in Bangladesh. It is also to be noted that Humidity in 7- and 14-days' lag have a strong positive association with death cases.

Table 4. The correlation coefficients between climatic parameters and numbers of death due to COVID-19.

\begin{tabular}{lllllllll}
\hline Variables & DHK & CTG & RAJ & SLY & MYM & RAN & BAR & KHU \\
\hline R (Rain on day) & 0.208 & 0.207 & 0.073 & $0.278^{*}$ & 0.089 & $0.274^{*}$ & -0.148 & -0.116 \\
R3 (Rain 3 days lag) & 0.038 & $0.231^{*}$ & $0.427^{* *}$ & 0.179 & -0.057 & $0.389^{* *}$ & -0.072 & -0.011 \\
R7 (Rain 7 days lag) & -0.074 & 0.178 & $0.239^{*}$ & $0.278^{*}$ & 0.052 & 0.198 & -0.129 & -0.013 \\
R14 (14 days lag) & 0.051 & $0.339^{* *}$ & 0.095 & $0.260^{*}$ & -0.039 & $0.353^{* *}$ & 0.084 & -0.010 \\
RH (Humidity on day) & $0.325^{* *}$ & 0.201 & 0.015 & $0.367^{* *}$ & 0.203 & $0.286^{*}$ & 0.026 & -0.152 \\
H3 (Humidity 3 days lag) & $0.223^{*}$ & 0.194 & $0.220^{*}$ & $0.336^{* *}$ & 0.004 & $0.384^{* *}$ & 0.052 & 0.030 \\
H7 (Humidity 7 days lag) & 0.151 & 0.190 & $0.352^{* *}$ & $0.341^{* *}$ & 0.072 & $0.377^{* *}$ & -0.012 & 0.092 \\
H14 (Humidity 14 days lag) & $0.344^{* *}$ & 0.017 & $0.308^{* *}$ & $0.427^{* *}$ & 0.024 & $0.387^{* *}$ & 0.153 & $0.351^{* *}$ \\
T (Temperature on day) & 0.074 & $0.669^{* *}$ & 0.056 & -0.191 & -0.144 & -0.150 & -0.020 & 0.192 \\
T3 (Temperature 3 days lag) & $0.320^{* *}$ & $0.730^{* *}$ & -0.199 & -0.046 & 0.129 & -0.203 & 0.070 & 0.164 \\
T7 (Temperature 3 days lag) & $0.307^{* *}$ & $0.733^{* *}$ & -0.152 & -0.006 & 0.033 & -0.074 & 0.053 & 0.154 \\
T14 (Temperature 14 days lag) & 0.013 & $0.746^{* *}$ & -0.053 & -0.145 & 0.125 & -0.124 & 0.112 & -0.115 \\
W (Wind speed on day) & $0.366^{* *}$ & $0.401^{* *}$ & -0.092 & 0.174 & -0.062 & 0.082 & 0.201 & 0.091 \\
W3 (Wind speed 3 days lag) & 0.200 & $0.341^{* *}$ & -0.132 & 0.107 & -0.116 & 0.162 & $0.218^{*}$ & 0.096 \\
W7 (Wind speed 7 days lag) & -0.015 & $0.315^{* *}$ & 0.043 & $0.260^{*}$ & 0.098 & 0.154 & 0.205 & 0.103 \\
W14 (wind speed 14 days lag) & 0.179 & 0.115 & $0.218^{*}$ & $0.255^{*}$ & 0.173 & $0.341 * *$ & $0.311^{* *}$ & $0.271 *$ \\
\hline ** Correlation is significant at the 0.01 level $*$ Correlation is significant at the 0.05 level. & &
\end{tabular}

** Correlation is significant at the 0.01 level; * Correlation is significant at the 0.05 level. 
Basray et al. [25] reported (Table 5) similar significant positive association ( $\mathrm{r}=0.59)$ in Karachi, Pakistan. Moreover, Lim et al. [28] also reported a positive association, although the correlation is very poor $(r=0.006)$. On the other hand, a negative association is reported by Ma et al. [29] and Sharif and Dey [9]. Few moderate to strong correlations are also found with rainfall events and COVID-19 death cases, especially in Chittagong, Sylhet and Rangpur. A significant positive association is found with temperature in mostly affected two cities (Dhaka and Chittagong). A similar positive correlation is found by many researchers in China and Europe [29-31]. The rest of the cities does not show any significant association, although few cities show negative correlations. In the case of wind speed, significant positive correlations were found with death cases. Chittagong and Dhaka cities show strong association with the day of reporting, 3 and 7 days earlier of the wind events. But the rest of the cities are showing significant association 14 days earlier of the wind events. Sharif and Dey also reported a similar positive relationship with wind speed and death rates [9].

Table 5. Association of climatic parameters with COVID-19 death cases reported in different studies.

\begin{tabular}{|c|c|c|c|c|c|c|}
\hline Study Area & $\begin{array}{l}\text { Rainfall } \\
\text { in mm (coef.) }\end{array}$ & $\begin{array}{l}\text { Temp in }{ }^{\circ} \mathrm{C} \\
\text { (coef.) }\end{array}$ & $\begin{array}{l}\text { Relative humidity } \\
\% \text { (coef.) }\end{array}$ & $\begin{array}{l}\text { Wind Speed } \\
\mathrm{kmh}^{-1} \text { (coef.) }\end{array}$ & Time period & Ref. \\
\hline $\begin{array}{l}\text { Cities in } \\
\text { Bangladesh }\end{array}$ & $\begin{array}{l}3.3-29.8 \\
(-0.010-0.427)\end{array}$ & $\begin{array}{l}22.8-34.5 \\
(-0.191-0.746)\end{array}$ & $\begin{array}{l}12-94 \\
(-0.012-0.427)\end{array}$ & $\begin{array}{l}3.3-46.8 \\
(-0.132-0.402)\end{array}$ & $\begin{array}{l}8 \text { Mar - 31 May } \\
2020\end{array}$ & $\begin{array}{l}\text { This } \\
\text { Study }\end{array}$ \\
\hline $\begin{array}{l}\text { Republic of } \\
\text { Korea }\end{array}$ & $\begin{array}{l}0-88.2 \\
(0.074) \\
\end{array}$ & $\begin{array}{l}-7.1-26.5 \\
(0.507)\end{array}$ & $\begin{array}{l}34-98.5 \\
(0.006)\end{array}$ & $\begin{array}{l}0.9-4.4 \\
(0.125)\end{array}$ & $\begin{array}{l}\text { 01 Jan-30 Aug } \\
2020\end{array}$ & [28] \\
\hline $\begin{array}{l}\text { Wuhan, } \\
\text { China }\end{array}$ & $\mathrm{n} / \mathrm{a}$ & $\begin{array}{l}7.44 \pm 3.96 \\
(0.30)\end{array}$ & $\begin{array}{l}82.24 \pm 8.51 \\
(-0.32)\end{array}$ & $\mathrm{n} / \mathrm{a}$ & $\begin{array}{l}20 \mathrm{Jan}-29 \mathrm{Feb} \\
2020\end{array}$ & [29] \\
\hline $\begin{array}{l}\text { Cities in } \\
\text { Pakistan }\end{array}$ & $\begin{array}{l}0.17-3.48 \\
(-0.26-0.081)\end{array}$ & $\begin{array}{l}1.87-33.99 \\
(-0.005-0.631)\end{array}$ & $\begin{array}{l}32.16-61.47 \\
(-0.557-0.107)\end{array}$ & $\mathrm{n} / \mathrm{a}$ & $\begin{array}{l}\text { 16 Feb-31 Jul } \\
2020\end{array}$ & [25] \\
\hline Bangladesh & $\mathrm{n} / \mathrm{a}$ & $\begin{array}{l}18-32 \\
(-0.346 \text { to }-0.598)\end{array}$ & $\begin{array}{l}55-85 \\
(-0.149 \text { to }-0.412)\end{array}$ & $\begin{array}{l}3-19 \\
(0.099-0.247)\end{array}$ & $\begin{array}{l}\text { 07 Mar- } 14 \text { Aug } \\
2020\end{array}$ & [9] \\
\hline $\begin{array}{l}\text { Dhaka } \\
\text { University, } \\
\text { Bangladesh }\end{array}$ & $\begin{array}{l}0-40.4 \mathrm{~mm} / \mathrm{hr} \\
(0.205)\end{array}$ & $\begin{array}{l}23.9-33.6 \\
(0.309)\end{array}$ & $\begin{array}{l}39.1-99.8 \\
(0.207)\end{array}$ & $\begin{array}{l}0.002-0.0183 \\
(0.053)\end{array}$ & $\begin{array}{l}08 \text { Mar-16 Jun } \\
2020\end{array}$ & [32] \\
\hline
\end{tabular}

Note: Correlation coefficients are kept within the bracket.

As seen in Tables 3 and 4, the correlation coefficients for different climatic variables with both COVID-19 positive cases and death cases are greater in magnitude than other studies elsewhere around the major cities of the world. The result indicates that an increase in a unit of any weather parameters may pose a relatively greater risk of transmission. This is a warning for warmer weather ahead in Bangladesh and in similar weather patterns elsewhere compared to other countries with significant differences. This indicates Bangladesh may face the severity of COVID-19 transmission on a community scale ahead unless necessary health regulations and control measures are taken. Furthermore, while elsewhere, rules and regulations and respect to laws by people might help to control the transmission within a shorter spell, in Bangladesh, the effectiveness of lockdown, people's perception of COVID-19, willingness to follow the health regulations 
were hardly seen worked so far and hence, increased rate of positive cases is continued with the increased temperature and humidity since April 2020.

\section{Conclusion}

The COVID-19 pandemic situation has unexpectedly stopped the steady life of people around the world. This study investigated the effects of four major weather parameters (temperature, rainfall, wind speed and relative humidity) on COVID-19 cases as well as the mortality rate in Bangladesh. The COVID-19 positive cases and death cases are found high in the two most densely populated cities (Dhaka and Chittagong) in Bangladesh and the rate is increasing alarmingly. A few rainfall events with low magnitude $(0-29.8 \mathrm{~mm})$ are found during April-May, 2020. Relative humidity varies between 12-94\%, whereas temperature is found in $25-36{ }^{\circ} \mathrm{C}$ range. Furthermore, wind speed in major cities was found to be at a rate of $4.8-47 \mathrm{~km} / \mathrm{h}$. The findings suggest greater number of relatively strong positive associations (0.24-0.581) between the relative humidity and positive cases than with rainfall (0.241-0.497) and wind speed (0.241-0.369), while temperature showed both positive and negative associations (-0.229-0.721). Furthermore, mostly strong positive association (-0.012-0.427) is found among humidity and numbers of COVID-19 death cases in most of the cities. Rainfall (-0.010-0.427), temperature (-0.191-0.746) and wind speed (-0.132-0.402) also show moderate to strong correlations in few cities of Bangladesh. Weather parameters also show negative correlations in few cities with weak association with death cases. The confirmed COVID-19 cases and a number of deaths are high in this division where human activities are high. It is recommended for further biological investigation in line with the association found between weather parameters with COVID-19 positive cases and death cases. Nevertheless, health regulations are to be implemented based on the results found ahead to maintain a comfortable pattern of COVID-19 cases and death tolls in Bangladesh.

\section{References}

1. M. F. Bashir, B. Ma, and L. Shahzad, Air Qual. Atmos. Health 13, 12 (2020). https://doi.org/10.1007/s11869-020-00894-8

2. S. Hassantabar, M. Ahmadi, and A. Sharifi, Chaos, Solitons and Fractals. 140, 110170 (2020). https://doi.org/10.1016/j.chaos.2020.110170

3. IEDCR, Institute of Epidemiology, Disease Control and Research (IEDCR) (2020). https://iedcr.gov.bd/ (accessed May 01, 2020)

4. A. A. Shawon (2020). https://www.dhakatribune.com/ (accessed May 11, 2020)

5. M. Haque and R. Ahamad (2020). https://www.newagebd.net/ (accessed May 11, 2020)

6. A. S. Ahmar and E. Boj, Curr. Res. Behav. Sci. 1, 100002 (2020). https://doi.org/10.1016/j.crbeha.2020.100002

7. Bilal, F. Latif, M. F. Bashir, B. Komal, and D. Tan, Psychiatry Res. 289, 113041 (2020). https://doi.org/10.1016/j.psychres.2020.113041

8. R. Mahin and S. H. Naqib, J. Sci. Res. 13, 2 (2020). https://doi.org/10.3329/jsr.v13i2.50273

9. N. Sharif and S. K. Dey, Epidemiol. Infect. 149,19 (2021). https://doi.org/10.1017/S0950268821000029 
10. M. Ahmadi, A. Shari, S. Dorosti, S. Jafarzadeh, and N. Ghanbari, Sci. Total Environ. 729, ID 138705 (2020). https://doi.org/10.1016/j.scitotenv.2020.138705

11. I. V Biktasheva, Sci. Total Environ. 736, ID 138763 (2020). https://doi.org/10.1016/j.scitotenv.2020.138763

12. Y. Ma, Y. Zhao, J. Liu, X. He, B. Wang, S. Fu, J. Yan, J. Niu, J. Zhou, and B. Luo, Sci. Total Environ. 724, ID 138226 (2020) https://doi.org/10.1016/j.scitotenv.2020.138226

13. Bilal, M. F. Bashir, B. Komal, M. Benghoul, M. A. Bashir, and D. Tan, Risk Manag. Healthc. Policy 14, 67 (2021). https://doi.org/10.2147/RMHP.S290153

14. H. Qi, S. Xiao, R. Shi, M. P. Ward, Y. Chen, W. Tu, Q. Su, W. Wang, X. Wang, and Z. Zhang, Sci. Total Environ. 728, ID 138778 (2020). https://doi.org/10.1016/j.scitotenv.2020.138778

15. M. Şahin, Sci. Total Environ. 728, ID 138810 (2020). https://doi.org/10.1016/j.scitotenv.2020.138810

16. M. M. Menebo, Sci. Total Environ. 737, ID 139659 (2020). https://doi.org/10.1016/j.scitotenv.2020.139659

17. R. Tosepu, J. Gunawan, D. Savitri, L. Ode, A. Imran, H. Lestari, H. Bahar, and P. As, Sci. Total Environ. 725, ID 138436 (2020) https://doi.org/10.1016/j.scitotenv.2020.138436

18. GoB, Government of the People's Republic of Bangladesh Ministry of Health and Family Welfare, Health Bulletin (2016) pp. 1-203.

19. BMD, Bangladesh Meteorological Department (2017). http://www.bmd.gov.bd/ (accessed Jun. 20, 2020)

20. DGHS, Directorate General of Health Services (2020). https://dghs.gov.bd/index.php/en/home (accessed Jun. 24, 2020)

21. S. K. Pani, N. Lin, and S. Ravindrababu, Sci. Total Environ. 740, ID 140112 (2020). https://doi.org/10.1016/j.scitotenv.2020.140112

22. M. F. Bashir, B. Ma, Bilal, B. Komal, and M. A. Bashir, Sci. Total Environ. 728, ID 138835 (2020). https://doi.org/10.1016/j.scitotenv.2020.138835

23. C. Spearman, The Concise Encyclopedia of Statistics (New York, NY: Springer New York, 2008) pp. 502-505,

24. Y. Yao, J. Pan, Z. Liu, X. Meng, W. Wang, H. Kan, and W. Wang, Eur. Respir. J. 55, ID 2000517 (2020). https://doi.org/10.1183/13993003.00517-2020

25. R. Basray, A. Malik, W. Waqar, A. Chaudhry, M. W. Malik, M. A. Khan, J. A. Ansari, and A. Ikram, J. Biosaf. Biosecurity, 3, 1 (2021). https://doi.org/10.1016/j.jobb.2021.02.001

26. K. Shahzad, U. Shahzad, N. Iqbal, F. Shahzad, and Z. Fareed, Res. Sq. 1 (2020). https://doi.org/10.21203/rs.3.rs-30377/v1

27. A. Gupta, S. Banerjee, and S. Das, Model. Earth Syst. Environ. 6, ID 0123456789 (2020). https://doi.org/10.1007/s40808-020-00838-2

28. Y. K. Lim, O. J. Kweon, H. R. Kim, T. H. Kim, and M. K. Lee, Sci. Rep. 11, 1 (2021). https://doi.org/10.1038/s41598-021-85493-y

29. Y. Ma, Y. Zhao, J. Liu, X. He, B. Wang, S. Fu, J. Yan, J. Niu, J. Zhou, and B. Luo, Sci. Total Environ. 724, ID 138226 (2020) https://doi.org/10.1016/j.scitotenv.2020.138226

30. G. Zhu, Y. Zhu, Z. Wang, W. Meng, X. Wang, J. Feng, J. Li, Y. Xiao, F. Shi, and S. Wang, BMC Public Health 21, 1 (2021). https://doi.org/10.1186/s12889-020-10131-7

31. C. Mattiuzzi, G. Lippi, and B. M. Henry, Public Health 193, 2021 (2021). https://doi.org/10.1016/j.puhe.2021.01.027

32. R. S. Pavel, A. Salam, M. Yesmin, N. Ahsan, S. U. Zaman, and F. Jeba, medRxiv 1 (2020). https://doi.org/10.1101/2020.09.12.20193086 